\title{
Survival of frozen-thawed mouse and rat embryos in the presence of ethylene glycol
}

\author{
H. Miyamoto and T. Ishibashi \\ Department of Animal Science, College of Agriculture, Kyoto University, Kyoto, Japan
}

Survival of mammalian embryos after storage at very low temperatures was first achieved in the mouse with suitably slow rates of cooling and thawing and in the presence of the dimethyl sulphoxide (DMSO) or glycerol (Whittingham, Leibo \& Mazur, 1972; Wilmut, 1972; Leibo, Mazur \& Jackowski, 1974). Similar procedures have been applied for the embryos of cattle (Wilmut \& Rowson, 1973), rabbit (Bank \& Maurer, 1974; Maurer \& Haseman, 1976), rat (Whittingham, 1975), and sheep (Willadsen, Polge, Rowson \& Moor, 1976) in the presence of DMSO. A report (Whittingham, 1971a) of the survival of mouse embryos frozen and thawed in medium containing polyvinylpyrrolidone (PVP) has not been confirmed (Whittingham et al., 1972; Wilmut, 1972) and no survival has been achieved for rabbit embryos frozen in the presence of PVP or glycerol (Bank \& Maurer, 1974). Greater survival was obtained for mouse embryos frozen in the presence of DMSO than in glycerol (Whittingham et al., 1972). It therefore seems that DMSO is more effective than glycerol for the protection of mammalian embryos from freezing damage. This communication reports the survival of mouse and rat embryos after freezing and thawing by using ethylene glycol as the cryoprotective agent.

Female ICR mice, 6-12 weeks old, were induced to superovulate by intraperitoneal injections of 5 i.u. PMSG and 5 i.u. HCG given approximately $48 \mathrm{~h}$ apart, and were mated. Eight-cell embryos were recovered from the oviduct and anterior portion of the uterine horns at 68-72 $\mathrm{h}$ after the injection of HCG. Eight-cell embryos were also obtained by flushing from Wistar rats, aged 10-15 weeks, on Day 4 of pregnancy (Day 1 is the day on which spermatozoa are found in the vagina) after natural mating. The mouse and rat embryos were collected in modified Dulbecco's phosphatebuffered salt solution (PBS solution: Whittingham, 1971a) and washed in several changes of PBS solution to remove debris. Between 10 and 22 embryos were placed in $\mathbf{0 . 1} \mathrm{ml}$ PBS solution contained in freezing tubes $(10 \times 100 \mathrm{~mm})$. Except where noted, the tubes were cooled to $0^{\circ} \mathrm{C}$ at $1{ }^{\circ} \mathrm{C} / \mathrm{min}$ in a Dewar flask containing ethanol, and ethylene glycol or DMSO in PBS solution was added to samples at $0^{\circ} \mathrm{C}$ in three increments of $0.05 \mathrm{ml}$ at $10 \mathrm{~min}$ intervals. The final concentration of ethylene glycol and DMSO was usually $1.2-1.5 \mathrm{M}$. The samples were equilibrated for $15 \mathrm{~min}$ at $0^{\circ} \mathrm{C}$, cooled to $-5^{\circ} \mathrm{C}$ and seeded with an ice crystal to induce ice formation. After 5 min they were cooled to $-79^{\circ} \mathrm{C}$ at approximately $0.5^{\circ} \mathrm{C} / \mathrm{min}$ by adding solid $\mathrm{CO}_{2}$ to ethanol. In some cases the Dewar flasks containing the samples were placed in liquid nitrogen vapour to be cooled from $-79^{\circ} \mathrm{C}$ to $-120^{\circ} \mathrm{C}$ at $0 \cdot 3-$ $0.5^{\circ} \mathrm{C} / \mathrm{min}$, and then samples were transferred directly to liquid nitrogen. Samples were kept at -79 or $-196^{\circ} \mathrm{C}$ for $1-3 \mathrm{~h}$ and thawed at approximately $15^{\circ} \mathrm{C} / \mathrm{min}$ in air at room temperature. Embryos were recovered and washed in three changes of a modified Krebs-Ringer bicarbonate medium (Whittingham, 1971b) at room temperature. Mouse embryos were transferred to drops of a modified Krebs-Ringer bicarbonate medium under paraffin oil, and rat embryos were transferred to drops of the same culture medium containing $10 \%$ fetal calf serum (Whittingham, 1975). These embryos were then cultured to assay viability by the microdrop method at $37^{\circ} \mathrm{C}$ for $48 \mathrm{~h}$ in $5 \% \mathrm{CO}_{2}$ in air $(\mathrm{Brinster}$, 1963). Survival was assessed by the ability of the frozen-thawed 8-cell embryos to develop into expanded blastocysts during culture. Data were analysed for statistical significance using a $\chi^{2}$ test.

The effect of ethylene glycol concentration on survival of 8-cell mouse embryos after freezing to $-79^{\circ} \mathrm{C}$ was examined. The percentage of survival of frozen and thawed embryos in $0 \cdot 6,0 \cdot 9,1 \cdot 2,1 \cdot 5$, $1 \cdot 8$ and $2 \cdot 1 \mathrm{M}$-ethylene glycol was $4(2 / 50), 80(32 / 40), 78(38 / 49), 71(25 / 35), 44(20 / 45)$ and $27(10 / 37)$, respectively. A concentration of 0.9-1.5 M-ethylene glycol appeared to be the best $(P<0.02)$, and we used 1.2 M-ethylene glycol for subsequent studies of the freezing of mouse"embryos. 
Table 1. Survival of 8-cell mouse and rat embryos after freezing and thawing in the presence of ethylene glycol or DMSO

\begin{tabular}{|c|c|c|c|c|c|c|}
\hline Species & $\begin{array}{l}\text { Cryoprotective } \\
\text { agent (conc.) }\end{array}$ & $\begin{array}{c}\text { Freezing } \\
\text { temp. } \\
\left({ }^{\circ} \mathrm{C}\right)\end{array}$ & $\begin{array}{l}\text { No. of } \\
\text { embryos } \\
\text { frozen }\end{array}$ & $\begin{array}{l}\text { No. of } \\
\text { embryos } \\
\text { recovered }\end{array}$ & $\begin{array}{l}\text { No. of } \\
\text { morulae } \\
\text { after } \\
\text { culture } \\
(\%)\end{array}$ & $\begin{array}{l}\text { No. of } \\
\text { blastocysts } \\
\text { after } \\
\text { culture } \\
(\%)\end{array}$ \\
\hline \multirow[t]{4}{*}{ Mouse } & DMSO (1.2 M) & -79 & 59 & 58 & - & $51(88)$ \\
\hline & DMSO $(1 \cdot 2 \mathrm{M})$ & -196 & 96 & 84 & - & $32(38)$ \\
\hline & Ethylene glycol $(1 \cdot 2 \mathrm{M})$ & -79 & 112 & 107 & - & $91(85)$ \\
\hline & Ethylene glycol $(1 \cdot 2 \mathrm{M})$ & -196 & 129 & 124 & - & $94(76)$ \\
\hline \multirow[t]{4}{*}{ Rat } & DMSO $(1.5 \mathrm{M})$ & -79 & 50 & 45 & $4(9)$ & $17(38)$ \\
\hline & DMSO $(1.5 \mathrm{M})$ & -196 & 38 & 36 & $2(6)$ & $10(28)$ \\
\hline & Ethylene glycol $(1 \cdot 2 \mathrm{M})$ & -79 & 44 & 38 & 4 (11) & $13(34)$ \\
\hline & Ethylene glycol (1.2 M) & -196 & 54 & 52 & $3(6)$ & $16(31)$ \\
\hline
\end{tabular}

The survival of 8-cell mouse embryos after freezing and thawing in the presence of DMSO or ethylene glycol is summarized in Table 1. There was no difference between DMSO and ethylene glycol in the survival of mouse embryos frozen to $-79^{\circ} \mathrm{C}$, but significantly higher $(P<0.001)$ survival was obtained with ethylene glycol after freezing to $-196^{\circ} \mathrm{C}$.

Eight-cell mouse embryos were stored for $3 \mathrm{~h}, 30$ or 180 days at $-196^{\circ} \mathrm{C}$ in the presence of 1.2 M-ethylene glycol. The survival of the embryos was $76(94 / 124), 71(57 / 80)$ and $78 \%$ (43/55), respectively. Viability was not therefore affected by storage in ethylene giycol at $-196^{\circ} \mathrm{C}$ for 180 days. This finding agrees with a previous report for 8-cell mouse embryos stored for 8 months at $-196^{\circ} \mathrm{C}$ in the presence of DMSO (Whittingham \& Whitten, 1974).

A further test of viability of the mouse embryos frozen to $-196^{\circ} \mathrm{C}$ in the presence of ethylene glycol was made by transfer of the embryos to the uterine horns of pseudopregnant recipients. Twenty expanded blastocysts, obtained after freezing and thawing 8-cell embryos and culturing them for a further $48 \mathrm{~h}$, were transferred to the uterine horns of 3 females on Day 3 of pseudopregnancy ( $6-8$ blastocysts/horn/female). One female, killed on Day 18 of pregnancy, had 4 morphologically normal fetuses.

To examine whether ethylene glycol must permeate 8-cell mouse embryos to protect them against freezing damage or not, the embryos were exposed to $1.2 \mathrm{M}$-ethylene glycol at $0^{\circ} \mathrm{C}$ for various periods after the direct addition of PBS solution containing ethylene glycol and frozen to $-79^{\circ} \mathrm{C}$. Survival after exposure for $0 \cdot 1,5,15,30$, and $60 \mathrm{~min}$ and subsequent freezing to $-79^{\circ} \mathrm{C}$ was $85(50 / 59), 75$ $(33 / 44), 79(48 / 61), 74(28 / 38)$, and $76 \%(45 / 59)$, respectively. Morphological observation of the embryos exposed to $1.2 \mathrm{M}$-ethylene glycol at 0 to $1^{\circ} \mathrm{C}$ for various periods showed that they shrank during the first $5 \mathrm{~min}$ of exposure, remained shrunken for the next $5 \mathrm{~min}$, and did not fully regain their normal volume even after $60 \mathrm{~min}$. These results demonstrate that permeation of ethylene glycol may not be required to protect 8-cell mouse embryos against freezing damage. Protection of such embryos against freezing damage without permeation of ethylene glycol would be consistent with previous reports of the protective action of DMSO and glycerol (Whittingham et al., 1972; Leibo, Mazur \& Jackowski, 1974).

The survival of 8-cell rat embryos after freezing and thawing in the presence of DMSO or ethylene glycol is also summarized in Table 1. These results show that ethylene glycol is as effective as DMSO for protecting rat embryos during freezing.

Ethylene glycol has been used as the cryoprotective agent for protection during freezing of other mammalian cells but it has afforded less effective protection than glycerol or DMSO (Meryman, 1966). We have demonstrated for the first time that ethylene glycol is able to protect 8-cell mouse and rat embryos from freezing damage, and ethylene glycol might be applied successfully as the cryoprotective agent to embryos of other species. 


\section{References}

BANK, H. \& MAURER, R.R. (1974) Survival of frozen rabbit embryos. Expl Cell Res. 89, 188-196.

BrINSTER, R.L. (1963) A method for in vitro cultivation of mouse ova from two-cell to blastocyst. Expl Cell Res. 32, 205-208.

Leibo, S.P., MAZur, P. \& JaCkowski, S.C. (1974) Factors affecting survival of mouse embryos during freezing and thawing. Expl Cell Res. 89, 79-88.

Maurer, R.R. \& Haseman, J.K. (1976) Freezing morula stage rabbit embryos. Biol. Reprod. 14, 256263.

Meryman, H.T. (Ed.) (1966) Cryobiology. Academic Press, New York.

WhitTINGHAM, D.G. (1971a) Survival of mouse embryos after freezing and thawing. Nature, Lond. 233, 125126.

Whittingham, D.G. (1971b) Culture of mouse ova. $J$. Reprod. Fert., Suppl. 14, 7-21.
WhItTINGHAM, D.G. (1975) Survival of rat embryos after freezing and thawing. J. Reprod. Fert. 43, 575578.

WhITTINGHAM, D.G. \& WhITTEN, W.K. (1974) Longterm storage and aerial transport of frozen mouse embryos. J. Reprod. Fert. 36, 433-435.

Whittingham, D.G., Leibo, S.P. \& MazuR, P. (1972) Survival of mouse embryos frozen to $-196^{\circ} \mathrm{C}$ and $-269^{\circ} \mathrm{C}$. Science, N.Y. 178, $411-414$.

Willadsen, S.M., Polge, C., Rowson, L.E.A. \& MoOR, R.M. (1976) Deep freezing of sheep embryos. J. Reprod. Fert. 46, 151-154.

WiLmuT, I. (1972) The effect of cooling rate, warming rate, cryoprotective agent and stage of development on survival of mouse embryos during freezing and thawing. Life Sci. 11, 1071-1079.

WiLmuT, I. \& Rowson, L.E.A. (1973) Experiments on the low-temperature preservation of cow embryos. Vet. Rec. 92, 686-690. 